\title{
Social Psychology Meets School Mathematics in PISA 2012: An Application of the Theory of Planned Behaviour in Australia
}

\author{
Grace Skrzypiec ${ }^{1}$, Mun Yee Lai ${ }^{2}$ \\ ${ }^{1}$ College of Education, Psychology and Social Work, Flinders University, Adelaide, Australia \\ ${ }^{2}$ School of Education, Australian Catholic University, Melbourne, Australia \\ Email: grace.skrzypiec@flinders.edu.au, MunYee.Lai@acu.edu.au
}

How to cite this paper: Skrzypiec, G., \& Lai, M. Y. (2017). Social Psychology Meets School Mathematics in PISA 2012: An Application of the Theory of Planned Behaviour in Australia. Psychology, 8, 2146-2137. https://doi.org/10.4236/psych.2017.813137

Received: September 28, 2017

Accepted: November 26, 2017

Published: November 29, 2017

Copyright (c) 2017 by authors and Scientific Research Publishing Inc. This work is licensed under the Creative Commons Attribution International License (CC BY 4.0).

http://creativecommons.org/licenses/by/4.0/

\begin{abstract}
Educators and government administrators are keen to find interventions to change the rapidly declining enrollments in senior high school mathematics. In 2012, PISA introduced measures to examine the Theory of Planned Behaviour (TPB), a prominent theory from social psychology for encouraging changes in behavior (and perhaps mathematics enrollments). This paper sought to examine the applicability of the TPB for predicting the relationship between students' intentions, their mathematics attitudes, subject norms, perceived controllability and self-efficacy as well as their mathematics behaviour, using items created by PISA 2012 question designers to assess these TPB constructs. Australian PISA 2012 data from 14,481 students found that the hypothesized TPB antecedents for studying mathematics were very poor predictors of mathematical intentions and indirectly, weak predictors of mathematical behaviour. The Attitudes factor i.e. an interest in mathematics, was found to be the strongest predictor of mathematical intentions. The poor predictive capacity of the TPB was proposed to have been due to ill-defined indicator items in the PISA 2012 measuring instruments, which did not comply with the TPB's principles of compatibility and aggregation. Future studies testing the TPB in the context of studying mathematics would benefit from undertaking Elicitation studies to identify appropriate TPB antecedents and indicators of the mathematics behaviour being targeted.
\end{abstract}

\section{Keywords}

Mathematics Intentions, PISA, Structured Equation Modelling, Theory of Planned Behaviour, Antecedents 


\section{Introduction}

In Australia, the number of school students choosing mathematics has been in apparent rapid decline. A study by Chinnappan, Dinham, Herrington and Scott (2008) reported that Australian school students' participation in mathematics subjects at high levels to Year 12 had been waning. However, Kennedy, Lyons and Quinn (2014) indicated that the Australian student enrollment rate in entry mathematics had been steadily increasing over the past 20 years, but that the enrollment rate in intermediate and advanced mathematics was almost the reverse image of entry mathematics. Forgasz (2006a) made a similar statement that declines in mathematics enrollment emerged as part of a trend away from specialized/advanced mathematics towards elementary/general mathematics, rather than a decline in total enrollments. Forgasz (2006b) suggested that the decline in intermediate and advanced mathematics enrollments could be due to the variation in student expectations of different courses. Other studies such as that by Lyons and Quinn (2010) and Thomas (2000) advised that diversification of curriculum offerings was likely to be another account for the declines.

Declining enrollments in mathematics subjects are of concern. No one would argue the fact that producing citizens who are mathematically capable is essential to keeping economic prosperity and remaining competitive in a global market place. In his study, Jeffries (2016) warned that workforce demand and economic growth are perhaps the two major areas affected by a declining number of individuals willing to undertake mathematics related degrees in universities. To explore and understand students' intentions to study mathematics in Australia, we considered an investigation of the PISA (The Programme for International Student Assessment) 2012 context questionnaire, which contained questions designed to explain student intentions and behaviour related to mathematics. It included items specifically designed to measure factors in the Theory of Planned Behaviour model (TPB, Fishbein \& Ajzen, 2005), namely students' mathematical attitudes, subjective norms and perceived controllability, as well as mathematics self-efficacy, mathematics study intentions and mathematics behaviour. The aim was to permit the application of this expectancy-value model. This was considered important as 'Students' attitudes and attributions, perceptions of control, and subjective norms may predict their work ethics and intentions-e.g. their desire to spend time on mathematics homework - their study behaviour and finally their mathematics performance" (OECD, 2014: 49). We expected that measuring and analyzing factors in the TPB model would provide information about Australian students' intentions to study mathematics and insights into the declining enrollments in mathematics subjects. Furthermore, an understanding of students' attitudes, subjective norms, perceived control, self-efficacy and intentions would inform an intervention to increase the likelihood of student engagement and continued involvement in mathematics. 


\section{Theory of Planned Behaviour}

The origin of the TPB lies in the hypothesis that the immediate antecedent of a particular behaviour is the intention to perform that behaviour (Ajzen, 1991; Fishbein \& Ajzen, 2005). Fishbein and Ajzen (1975) considered that since many other variables can influence whether or not an action will actually be undertaken, it was the intention to engage in a behaviour that should be the major focus of the theory (e.g., a villager might intend to shoot a charging lion, but may not be able to because she or he has no gun). Intention in this theory is described as a function of three independent determinants, namely attitudes, subjective norms and perceived behavioural control (Ajzen, 1991).

The TPB is considered to be a crucial social cognitive model that aims to describe different variances in volitional behaviour (Armitage \& Conner, 2001). The TPB has been successfully applied to the areas of public health and it is perhaps the most influential theory for the prediction of social and health behaviour (Rivis \& Sheeran, 2003). However, the TPB has never been applied to the learning of mathematics. A questionnaire administered as part of the PISA suite of questions sought to address the paucity of research in this area and enable an investigation of the TPB for studying mathematics. Our study has used the questions from PISA 2012, which were designed to measure each of the factors in the TPB model, shown in Figure 1, to investigate the applicability of the TPB in the field of mathematics education.

The TPB has been developed by considering an individual's psychological processes of cognitive self-regulation using a behavioural disposition approach (Ajzen, 1988). It is a theory that has been designed to explain and predict human behaviour in the social context (Ajzen, 1991). The underlying concept of the TPB is that some behaviour such as for example choosing to study mathematics, is not completely intentional and under volitional control, i.e., "if the person can decide at will to perform or not perform the behaviour" (Ajzen, 1991: 182). In an Australian context where the number of school students choosing mathematics has been in rapid decline, the TPB is well suited for an investigation of adolescents' intentions to study mathematics.

Conner and Armitage (1998: 1430) have reported that the TPB was "designed to provide parsimonious explanations of informational and motivational influences on behaviour". According to Fishbein (2008), it is by addressing the small number of antecedents underlying a specific behaviour, such as attitudes,

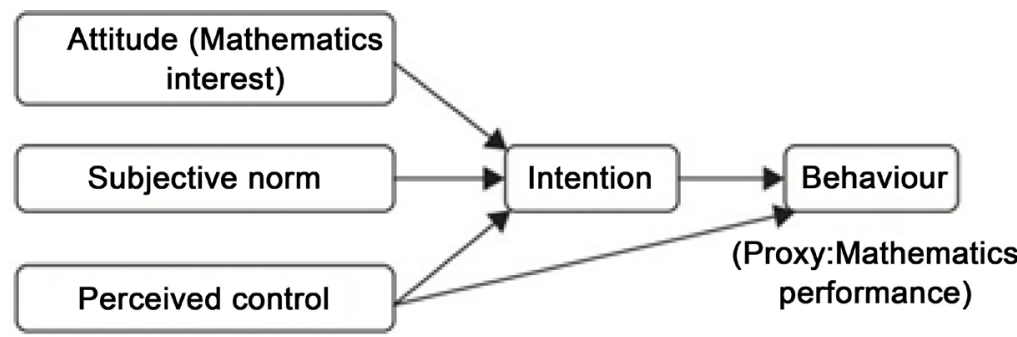

Figure 1. Model of the theory of planned behaviour in PISA 2012. 
subjective norms and perceived behavioural control that changes in behaviour may be instigated. In other words, applied to the context of studying mathematics, the TPB has the potential to identify suitable antecedents that could be addressed to increase the number of students voluntarily choosing to study mathematics through an intervention designed with these antecedents in mind.

Although the TPB has been generously employed in the health domain, Ajzen and Manstead (2007: 10) surmised that the theoretical conclusions of the TPB "hold equally well for behaviour in other domains ... [and] ... suffice it to note that, generally speaking, the theory has been well supported". Meta-analyses carried out by various researchers, which have examined the veracity of the TPB, have found mean correlations that have ranged from 0.44 to 0.56 for the intention-behaviour relationship (see Albarracin, Johnson, Fishbein, \& Muellerleile, 2001; Godin \& Kok, 1996; Hausenblas, Carron, \& Mack, 1997; Sheeran \& Orbell, 1998) and from 0.63 to 0.71 for the prediction of intentions based on attitudes, subjective norms and perceived behavioural control (see Albarracin, Johnson, Fishbein, \& Muellerleile, 2001; Godin \& Kok, 1996; Hagger, Chatzisarantis, \& Biddle, 2002; Sheeran \& Taylor, 1999). Using the TPB as a basis for investigations of students' intentions to study mathematics is therefore not without merit. Applied in this study, the behaviour of interest in the TPB was students' involvement in mathematics, considered to be partly under volitional control and partly under non-volitional control. Building on this idea, this study considered that the TPB might be able to depict more accurate relationships between students' intentions and their mathematics behaviour and attitudes. Before embarking on this research however, a clear explanation of the constructs of TPB and their relationship with studying mathematics will provide clarity about the TPB antecedents.

\section{The Constructs in the TPB}

\subsection{Attitudes}

Attitudes are viewed as a crucial factor to be taken into account when explaining variability in students' mathematics performance (Kogce, Yildiz, Aydin, \& Altindag, 2009; Mohamed \& Waheed, 2011; Nicolaidou \& Philippou, 2003). However, previous work on defining attitude in this field was criticized by McLeod (1987) as being driven by "statistical methodology" rather than by theories, while Zan and Di Martino (2008) declared that it lacked theoretical clarity. A primary reason for the difficulty in defining attitude lies in the consideration of its multidimensional properties (Di Martino \& Zan, 2010; Hanulla, 2002; Kadijevich, 2006). Overall, the definition of attitude has not been clear in the way that both instruments and constructs have been portrayed without appropriate theoretical elaboration for mathematics education (Di Martino \& Zan, 2010). Zan and Di Martino (2008) even argued that the attitude measuring instruments did not only measure "attitude" but also achievement. More importantly, Ma and Kishor (1997), after a meta-analysis of the relationship between attitude and 
mathematics achievement in 113 studies, concluded that this correlation was not statistically significant because of the inappropriateness of the measuring instruments that were used. Other studies in the relationship between attitude and mathematics achievement, such as Georgiou, Stavrinides, and Kalavana (2007), Lipnevich, MacCann, Krumm, Burrus, and Roberts (2011), Ma and Xu (2004), Mata, Monteiro, and Peixoto (2012), and Mato Vázquez and de la Torre Fernández (2009), revealed inconsistent results from each other.

In deriving a definition of attitude in social psychology, Fishbein and Ajzen (1975) construed that "most investigators would probably agree with a description (or definition) of attitude as a learned predisposition to respond in a consistently favourable or unfavourable manner with respect to a given objects" (p.10). TPB researchers determined that attitudes comprise two sub-constructs of instrumental (e.g., desirable-undesirable, valuable-worthless) as well as experiential (e.g., pleasant-unpleasant, interesting-boring) aspects (Ajzen \& Driver, 1992; Crites, Fabrigar, \& Petty, 1994) so that measures of attitudes should include items that reflect these two elements. In PISA 2012 student interest in mathematics was considered to be indicative of students' attitudes toward mathematics. It could be argued that "interest" would reflect both attitude sub-constructs because an individual interested in mathematics would find mathematics desirable (instrumental) and pleasant (experiential).

\subsection{Subjective Norms}

In the TPB, subjective norms are generally referred to as "the individual's perceptions of general social pressure to perform (or not to perform) the behaviour" (Armitage \& Conner, 2001: 474). Armitage and Conner (2001) have stated that if an individual perceives that significant others (such as parents and friends) approve (or disapprove of) the behaviour, they are more (or less) likely to intend to perform the given behaviour. The overall subjective norms an individual holds about a particular behaviour is associated with her/his normative beliefs about what others expect with regard to the behaviour in question. Whether subjective norms exert social pressure to perform the action, however, is determined by the motivation to comply with these beliefs (Fishbein \& Ajzen, 1975).

Research has found two sub-constructs of subjective norms that include injunctive and descriptive or behavioural norms (Cialdini, 2003; Kashima, Gallois, \& McCamish, 1993). Injunctive subjective norms are associated with the perceptions of what others think one should do while descriptive or behavioural subjective norms concern the perception of what others are doing with regard to the behaviour in question. For example, a person may feel motivated to comply with the family's expectations to engage in mathematical activities or alternatively, motivated to comply with the norms of schoolmates who do not engage in mathematical activities. The addition of descriptive norms reveals that the normative pressure should include social pressure of significant others who may or may not execute the given behaviour (White, Terry, \& Hogg, 1994). Empirically, 
both injunctive and descriptive norms are significantly and highly correlated (Berg, Jonsson, \& Conner, 2000; Sheeran, Norman, \& Orbell, 1999) and thus assumed to independently depict behavioural intentions in the TPB (Hagger \& Chatzisarantis, 2005). Building on this idea, questions about the TPB in PISA 2012 appear to have adopted a more global normative influence construct in which subjective norms referred to both the injunctive and descriptive with a focus on measuring the influence of parents and peers.

Existing literature has consistently reported that parents' and peers' attitudes and behaviour towards mathematics represent two major environmental influences on children's formation of academic attitudes (Jacobs \& Bleeker, 2004; Jacobs \& Eccles, 2000; Ryan \& Patrick, 2001; Tiedemann, 2000; Yee \& Eccles, 1988). Studies by researchers such as Armstrong (1980), Eccles (1983), Jacobs and Bleeker (2004), and Jacobs and Eccles (2000) have suggested that parents' beliefs about mathematics might contribute to their children's mathematics course enrolment decisions. Jacobs and Bleeker (2004) also reported that parents' mathematics-promoting behaviour was related to their children's later interests and activities.

Friends' values and attitudes also play an important role in shaping and reinforcing beliefs, attitudes and behaviours of individuals (Ma, 2001; Sage \& Kindermann, 1999). Johnson and Johnson (2005) have stated that when individuals share similar goals in a peer group their actions affect each other's behaviour. Similarly, Kaplan, Middleton, Urdan, and Midgley (2002) pointed out that the personal goals of each individual in a classroom are related to and influenced by the classroom's goals.

Overall, interactions with parents and peers shape students' mathematics attitudes (Gunderson, Ramirez, Levine, \& Beilock, 2012). Parents own mathematics beliefs and behaviour also impact their children's mathematics' attitudes. Ma (2001) concluded that the influence of parents and peers for mathematics participation is necessary but insufficient to explain mathematics behavioural achievement. In the PISA 2012 questionnaire, items about subjective norms appear to have been designed to tap both of these facets of normative behaviours.

\subsection{Perceived Controllability and Self-Efficacy}

As mentioned, the underlying concept of the TPB is that some behaviour is not completely intentional and under volitional control. In the TPB, Ajzen's (1985) fundamental idea for including perceived behavioural control (PBC) was to describe the aspects of the given behaviour that are not completely under volitional control. Perceived behavioural control generally is referred to as the perceived ease or difficulty of undertaking an action or behaviour.

Researchers (for example, Trafimow, Sheeran, Conner, \& Finlay, 2002) revealed two distinct item clusters and thus suggested that $\mathrm{PBC}$ was composed of two separate components. Ajzen (2002) has since labelled these two PBC item 
clusters perceived controllability (i.e., the extent that an individual can exert control over the given behaviour) and self-efficacy (i.e., an individual's self-confidence for engaging in the given behaviour). Hagger and Chatzisarantis (2005: 517) specified that "measures of perceived controllability have often focused on statements regarding the degree of subjective control an individual has over the target behaviour". Statements like "if I wanted to, I could do well in mathematics" tap this component. Whereas, self-efficacy is tapped using items referring to the perceived capabilities toward participating in the target behaviour. In PISA 2012, statements like "how confident do you feel about calculating the petrol consumption rate of a car?" suggest that such items were designed to address this component. A substantial body of empirical evidence (Armitage, 1997; Dzewaltowski, Noble, \& Shaw, 1990; Manstead \& Eekelen, 1998; McCaul, Sandgren, O'Neill, \& Hinsz, 1993) has been provided to support the theoretical distinction between perceived controllability and self-efficacy. As behaviours differ in the degree of their volitional control, the differences yield uneven results in the prediction of different behaviours (Conner \& Armitage, 1998), though these two components share some common variance. For instance, perceived controllability was found to be a significant predictor of exercise behaviour (Terry \& O'Leary, 1995) whilst self-efficacy predicted English achievement (Manstead \& Eekelen, 1998). Conner and Armitage (1998) have indicated that academic achievement is relatively more dependent on skills and resources and thus more dependent on ones' self-efficacy. Appearing to implement this idea, TPB questions in PISA 2012 included both self-efficacy and perceived controllability as two discrete constructs.

Researchers (for example, Chen, 2002; Hoffman, 2010; Kalaycioglua, 2015; Pajares \& Graham, 1999; Siegel, Galassi, \& Ware, 1985; Stevens, Olivarez, Lan, \& Tallent-Runnels, 2004) who investigated the relationship between mathematics self-efficacy and mathematics performance have reported significant positive results. Although most research has reported a significant relationship between self-efficacy and mathematics performance, the measures have varied in strength (Chen, 2002). This may be due to the predictability of self-efficacy measures which depend on their specificity and correspondence to actual mathematics performance tasks (Zimmerman, 1995). Both self-efficacy and perceived control questions were present in the PISA 2012 questionnaire and as such permitted further examination of the predictive capacity of these constructs.

\section{The Present Study}

An exploration of the TPB model (shown in Figure 1) using items included in PISA 2012 designed to measure attitudes towards mathematics (as interest), subjective norms (of parents and peers) and perceived behavioural control (as perceived controllability and self-efficacy), as well as mathematics intentions and behaviour, formed the goal of this study. Improving our understanding of what influences students to study mathematics could inform interventions designed to 
increase participation in mathematics. Such an approach has been advocated by Ajzen and Albarracin (2007: 4): "Fishbein and Ajzen proposed that we identify a particular behaviour and then look for antecedents that can help to predict and explain the behaviour of interest, and thus potentially provide a basis for interventions designed to modify it."

According to Fishbein (2008), it is by addressing the small number of antecedents underlying a specific behaviour, such as attitudes, subjective norms and perceived behavioural control that changes in behaviour may be instigated. The aim of this study was therefore to determine the antecedents of students' mathematical intentions. Evidence of the TPB model would provide guidance of what factors could be addressed in order to influence student intentions to study mathematics.

\section{Method}

Our data were selected from scales provided in the PISA (2012) survey on Student Context Questionnaires (see OECD, 2012: 223-242) designed to enable the application of the Theory of Planned Behaviour (see OECD, 2014: 60). These included items that measured students' attitudes to mathematics, subjective norms, perceived controllability, mathematics self-efficacy, intentions and mathematics behaviour (as indicated in Table 1 below).

\subsection{Schools}

In our study, only the Australian data were analyzed. The Australian PISA 2012 school sample consisted of 775 schools located in different states and territories, stratified by school sector, geographical location, gender, socioeconomic background and achievement (see Thomas, De Bortoli, \& Buckley, 2013). Of the Australian PISA schools, $85 \%$ were coeducational, $8 \%$ catered for all-female students and $7 \%$ catered for all-male students. The 775 schools represented a weighted responses rate of $97.9 \%$, meeting the international standards on response rates (a minimum response rate of $85 \%$, weighted and unweighted, was required) as specified by the PISA Technical Advisory Group (Thomas, De Bortoli, \& Buckley, 2013).

\subsection{Student Participants}

The Australian PISA 2012 sample of 14,481 students was drawn from all jurisdictions and school sectors. In each school, 20 students and all age-eligible Indigenous students were sampled to participate. Overall, $3 \%$ of the sample was identified as Indigenous. The target population in Australia covered students who were aged between 15 years and 3 completed months to 16 years and 2 completed months at the time of the assessment. As the sample is age-based, the students came from various year levels but they were mostly from Years 9 (11\%), $10(70 \%)$ and 11 (19\%) (Thomas, De Bortoli, \& Buckley, 2013). Among all the participating non-Indigenous students, almost three-quarters (74\%) of students 
Table 1. Indicator items of each antecedent factor in the TPB model.

\begin{tabular}{|c|c|c|}
\hline TPB Antecedent & $\begin{array}{l}\text { PISA } 2012 \\
\text { Item number }\end{array}$ & Item \\
\hline \multirow{5}{*}{ Attitudes } & ST29Q1 & I enjoy reading about mathematics. \\
\hline & ST29Q3 & I look forward to my mathematics lessons. \\
\hline & ST29Q4 & I do mathematics because I enjoy it. \\
\hline & ST29Q6 & I am interested in the things I learn in mathematics. \\
\hline & ST35Q1 & Most of my friends do well in mathematics. \\
\hline \multirow{5}{*}{ Subjective norms } & ST35Q2 & Most of my friends work hard at mathematics. \\
\hline & ST35Q3 & My friends enjoy taking mathematics tests. \\
\hline & ST35Q4 & My parents believe it's important for me to study mathematics. \\
\hline & ST35Q5 & My parents believe that mathematics is important for my career. \\
\hline & ST35Q6 & My parents like mathematics. \\
\hline \multirow{6}{*}{ Perceived control } & ST43Q1 & If I put in enough effort, I can succeed in mathematics. \\
\hline & ST43Q2 & Whether or not I do well in mathematics is completely up to me. \\
\hline & ST43Q3 & $\begin{array}{l}\text { Family demands or other problems prevent me from putting a } \\
\text { lot of time into my mathematics work. }\end{array}$ \\
\hline & ST43Q4 & If I had different teachers, I would try harder in mathematics. \\
\hline & ST43Q5 & If I wanted to, I could do well in mathematics. \\
\hline & ST43Q6 & I do badly in mathematics whether or not I study for my exams. \\
\hline \multirow{8}{*}{ Self-efficacy } & ST37Q1 & $\begin{array}{l}\text { Using a train timetable to work out how long it would take to } \\
\text { get from one place to another. }\end{array}$ \\
\hline & ST37Q2 & Calculating how much cheaper a TV would be after a $30 \%$ discount. \\
\hline & ST37Q3 & $\begin{array}{l}\text { Calculating how many square metres of tiles you need to cover } \\
\text { a floor. }\end{array}$ \\
\hline & ST37Q4 & Understanding graphs presented in newspapers. \\
\hline & ST37Q5 & Solving an equation like $3 x+5=17$. \\
\hline & ST37Q6 & $\begin{array}{l}\text { Finding the actual distance between two places on a map with a } \\
1: 10,000 \text { scale. }\end{array}$ \\
\hline & ST37Q7 & Solving an equation like $2(x+3)=(x+3)(x-3)$. \\
\hline & ST37Q8 & Calculating the petrol-consumption rate of a car. \\
\hline
\end{tabular}

attended schools that were located in metropolitan areas, one-quarter (25\%) were from provincial areas and the remaining students (1\%) attended schools in remote areas (Thomas, De Bortoli, \& Buckley, 2013). A different distribution was found for participating Indigenous students: $46 \%$ of students were from metropolitan schools, $45 \%$ from provincial schools and $9 \%$ from remote schools (Thomas, De Bortoli, \& Buckley, 2013). Almost 90\% of the participating students indicated English was spoken at home most of the time while $10 \%$ of students indicated they spoke a language other than English at home (Thomas, De Bortoli, \& Buckley, 2013). In Australia, the PISA assessment took place in a 
six-week period from late July to early September 2012, meeting the PISA requirement that testing should take place in the second half of the academic year.

\subsection{PISA 2012 Student Context Questionnaires}

To increase the content coverage of topics of interest in the questionnaire without increasing the response time for individual students, rotated student context questionnaires were used in the main data collection in PISA 2012. Students were randomly assigned one of three questionnaires. Each questionnaire comprised a common part (questions about the student and their family background) and a rotated part, comprising questions about attitudinal and other non-cognitive constructs. In the PISA 2012 student questionnaire, three categories including students' attitudes, subject norms, perceived controllability and self-efficacy of mathematics, as well as intentions and mathematics behaviour were designed to enable the exploration of the TPB. These categories formed the major part of data in this study.

\subsection{TPB Items}

Indicator items in the PISA 2012 student context questionnaire that reflected each of the antecedents of attitudes (four items ST29Q1, ST29Q3, ST29Q4, ST29Q6), subjective norms (six items ST35Q1-ST35Q6) perceived control (four items ST43Q3-ST43Q6) and self-efficacy (eight items ST37Q1-ST37Q8) are listed in Table 1. For all statements, students were asked to rate their level of agreement on a four-point Likert scale: strongly agree; agree; disagree; strongly disagree.

To measure mathematical intentions (five items ST48Q1- ST48Q5), participants were asked to select one answer from each pair (a)-(d) in a "forced choice" format as shown in Table 2. Using this item type forced "students to choose between mathematics and some other subject like language or science with respect to additional courses at school and beyond" (OECD, 2014: 323). For example, in question ST48Q3 participants were asked to determine whether they intended to work harder in mathematics than in English.

Table 2. Indicator items of intentions to study mathematics in the TPB model.

\begin{tabular}{cl}
\hline Intentions & $\begin{array}{c}\text { Item } \\
\text { number }\end{array}$ \\
ST48Q1 & $\begin{array}{l}\text { I intend to take additional mathematics courses after school finishes vs. I } \\
\text { intend to take additional English courses after school finishes. }\end{array}$ \\
ST48Q2 & $\begin{array}{l}\text { I plan on majoring in a subject in college that requires mathematics skills vs. } \\
\text { I plan on majoring in a subject in college that requires science skills. }\end{array}$ \\
ST48Q3 & $\begin{array}{l}\text { I am willing to study harder in my mathematics classes than is required vs. I } \\
\text { am willing to study harder in my English classes than is required }\end{array}$ \\
ST48Q4 & $\begin{array}{l}\text { I plan on taking as many mathematics classes as I can during my education } \\
\text { vs. I plan on taking as many science classes as I can during my education. }\end{array}$ \\
ST48Q5 & $\begin{array}{l}\text { I am planning on pursuing a career that involves a lot of mathematics vs. I } \\
\text { am planning on pursuing a career that involves a lot of science. }\end{array}$ \\
\hline
\end{tabular}


Table 3. Indicator items of mathematical behaviour.

\begin{tabular}{lcl}
\hline Behaviour & Item number & \multicolumn{1}{c}{ Item } \\
\hline ST49Q1 & I talk about mathematics problems with my friends. \\
ST49Q2 & I help my friends with mathematics \\
ST49Q3 & I do mathematics as an activity \\
ST49Q4 & I take part in mathematics competitions \\
ST49Q5 & I do mathematics more than 2 hours a day outside of school. \\
ST49Q6 & I play chess \\
ST49Q7 & I program computers. \\
ST49Q9 & I participate in a mathematics club. \\
\hline
\end{tabular}

Eight items (ST49Q1- ST49Q8), shown in Table 3, measured mathematical behaviour both in and outside school. Participants were asked to rate how often they undertook each behaviour on a four-point scale: "Always or almost always", "Often", "Sometimes" and "Never or rarely".

\subsection{Data Analysis}

PISA 2012 unit record data was used in the analyses. Items were reversed scored so that agreement was reflected by a higher number. Structural Equation Modelling in MPlus was used to test the components of the TPB model as well as the model itself. The Confirmatory Factor Analyses (CFA) undertaken used Robust Maximum Likelihood Estimation in MPlus v7. The estimation measurement "type = complex", which is robust against non-independence (Muthén \& Muthén, 2009), was used to account for error associated with the nested data (i.e. students in classes, in schools and in states). Each factor model was trimmed and adjusted following Kline's (2011) recommendations before being included in the final TPB model (see Appendix A). This was to eliminate the possibility of a poor-fitting TPB model being due to ill-fitting factors within the model.

Cut-offs for model fit decisions followed Brown's (2006) suggestions that "support for contentions of reasonably good fit ... is obtained in instances where 1) SMR values are close to 0.08 or below; 2) RMSEA values are close to 0.06 or below; and 3) CFI and TLI values are close to 0.95 or greater" (p. 87). Browne and Cudeck's (1993) rule of thumb that RMSEA values between 0.1 and 0.08 represent a "mediocre fit", values less than 0.08 indicate an "adequate" model fit, values less than 0.05 suggests a "good" model fit, while values greater than or equal to 0.1 should be rejected, was implemented.

Hancock and Mueller's (2001) "coefficient H" was used instead of Cronbach's alpha to compute factor reliability. This is because in congeneric models Cronbach's alpha represents the lower bound of the true estimate of reliability (Brunner \& Heinz-Martin, 2005; Holmes-Smith \& Rowe, 1994) while the algorithm used to calculate " $\mathrm{H}$ " incorporates the weight of the scale indicators, recognizing that indicators contribute unequally to the factor (Brunner \& Heinz-Martin, 
2005). For this reason coefficient $\mathrm{H}$ is considered to be a better measure of reliability. In accord with Cronbach's alpha, values of $\mathrm{H}$ above 0.70 suggest that a factor is reliable (Hancock \& Mueller, 2001).

\section{Results}

\subsection{TPB Components}

Antecedent factors i.e. attitudes, subjective norms, perceived controllability and self-efficacy, as well as measures of mathematical intentions and behaviour were examined as one factor congeneric models prior to being placed in the TPB model. The standardized factor loading for each item in the factor (determined from the CFA of the one factor congeneric model) is reported in Table 4 (see also Appendix A).

The Attitudes factor showed excellent reliability, with a $\mathrm{H}$ coefficient of.912 (See Appendix A Figure S1). The best fit with the data for the subjective norms factor was when the subjective norms of parents and friends were separated into two distinct constructs (see Appendix A Figure S2). The reliability of the friends subjective norms factor was satisfactory $(\mathrm{H}=0.755)$ although the reliability of the parents subjective norms factor was low $(\mathrm{H}=0.663)$.

Following guidelines by Kline (2011) trimming resulted in two items being dropped in the perceived controllability factor, namely items ST43Q3 (Family demands or other problems prevent me from putting a lot of time into my mathematics work-a double barreled question) and ST43Q4 (If I had different teachers, I would try harder in mathematics - not clear as a "different" teacher is not defined). Similarly, two items, item ST37Q4 (understanding graphs presented in newspapers-assumes students read newspapers with graphs) and ST37Q8 (calculating the petrol-consumption rate of a car-confusing as 15 year olds in Australia do not drive) in the self-efficacy factor were also dropped. These items were dropped from each factor when analyses indicated that they were not good indicator items. Satisfactory reliability was evident for both the perceived controllability $(\mathrm{H}=0.755)$ and self-efficacy $(\mathrm{H}=0.857)$ factors (See Appendix A Figure S3 \& Figure S4, respectively).

\subsection{Mathematics Intentions}

Following trimming, where ambiguous item ST48Q1 (I intend to take additional mathematics courses after school finishes vs. I intend to take additional English courses after school finishes), was dropped, and allowing two items that were associated with post-high school studies (ST48Q2-I plan on majoring in a subject in college that requires mathematics skills vs. I plan on majoring in a subject in college that requires science skills and ST48Q5-I am planning on pursuing a career that involves a lot of mathematics vs. I am planning on pursuing a career that involves a lot of science) to correlate, the intentions construct fit the data well. As shown in Table 5, the reliability of the mathematical intentions factor was good with a $\mathrm{H}$ coefficient of 0.851 (see also Appendix A Figure S5). 
Table 4. The reliability of factors and factor loadings of antecedents indicator items in the TPB mathematics model.

\begin{tabular}{|c|c|c|c|}
\hline Antecedents & $\begin{array}{l}\text { Item } \\
\text { number }\end{array}$ & Item & Factor loading \\
\hline \multirow{4}{*}{$\begin{array}{c}\text { Attitudes } \\
\text { Coeff } \mathrm{H}=0.912\end{array}$} & ST29Q1 & I enjoy reading about mathematics. & 0.792 \\
\hline & ST29Q3 & I look forward to my mathematics lessons. & 0.831 \\
\hline & ST29Q4 & I do mathematics because I enjoy it. & 0.892 \\
\hline & ST29Q6 & I am interested in the things I learn in mathematics. & 0.850 \\
\hline \multirow{6}{*}{$\begin{array}{c}\text { Subjective norms } \\
\text { Coeff } \mathrm{H} \text { (sn-parents })=0.663 \\
\text { Coeff } \mathrm{H} \text { (sn-friends })=0.755\end{array}$} & ST35Q1 & Most of my friends do well in mathematics. & 0.687 \\
\hline & ST35Q2 & Most of my friends work hard at mathematics. & 0.810 \\
\hline & ST35Q3 & My friends enjoy taking mathematics tests. & 0.473 \\
\hline & ST35Q4 & My parents believe it's important for me to study mathematics. & 0.584 \\
\hline & ST35Q5 & My parents believe that mathematics is important for my career. & 0.546 \\
\hline & ST35Q6 & My parents like mathematics. & 0.712 \\
\hline \multirow{6}{*}{$\begin{array}{l}\text { Perceived controllability } \\
\quad \text { Coeff } \mathrm{H}=0.755\end{array}$} & ST43Q1 & If I put in enough effort, I can succeed in mathematics. & 0.705 \\
\hline & ST43Q2 & Whether or not I do well in mathematics is completely up to me. & 0.652 \\
\hline & ST43Q5 & If I wanted to, I could do well in mathematics. & 0.717 \\
\hline & ST43Q6 & I do badly in mathematics whether or not I study for my exams. & -0.477 \\
\hline & ST43Q3 & $\begin{array}{l}\text { Family demands or other problems prevent me from putting a lot of time into } \\
\text { my mathematics work. }\end{array}$ & dropped \\
\hline & ST43Q4 & If I had different teachers, I would try harder in mathematics. & dropped \\
\hline \multirow{8}{*}{$\begin{array}{c}\text { Self-efficacy } \\
\text { Coeff } \mathrm{H}=0.857\end{array}$} & ST37Q1 & $\begin{array}{l}\text { Using a train timetable to work out how long it would take to get from one } \\
\text { place to another. }\end{array}$ & 0.591 \\
\hline & ST37Q2 & Calculating how much cheaper a TV would be after a $30 \%$ discount. & 0.774 \\
\hline & ST37Q3 & Calculating how many square metres of tiles you need to cover a floor. & 0.795 \\
\hline & ST37Q5 & Solving an equation like $3 x+5=17$. & 0.642 \\
\hline & ST37Q6 & Finding the actual distance between two places on a map with a 1:10,000 scale. & 0.704 \\
\hline & ST37Q7 & Solving an equation like $2(x+3)=(x+3)(x-3)$. & 0.599 \\
\hline & ST37Q4 & Understanding graphs presented in newspapers. & dropped \\
\hline & ST37Q8 & Calculating the petrol-consumption rate of a car. & dropped \\
\hline
\end{tabular}

Table 5. Indicator items of intentions to study mathematics in the TPB model.

\begin{tabular}{cclcc}
\hline Intentions & Item number & Item & Factor loading \\
\hline ST48Q1 & $\begin{array}{l}\text { I intend to take additional mathematics courses after school finishes vs. I intend } \\
\text { to take additional English courses after school finishes. }\end{array}$ & dropped \\
Coeff $\mathrm{H}=0.851$ & ST48Q2 & $\begin{array}{l}\text { I plan on majoring in a subject in college that requires mathematics skills vs. I } \\
\text { plan on majoring in a subject in college that requires science skills. }\end{array}$ & $\begin{array}{l}\text { I am willing to study harder in my mathematics classes than is required vs. I am } \\
\text { willing to study harder in my English classes than is required. }\end{array}$ & 0.771 \\
& & ST48Q4 & $\begin{array}{l}\text { I plan on taking as many mathematics classes as I can during my education vs. I } \\
\text { plan on taking as many science classes as I can during my education. }\end{array}$ & 0.845 \\
& ST48Q5 & $\begin{array}{l}\text { I am planning on pursuing a career that involves a lot of mathematics vs. I am } \\
\text { planning on pursuing a career that involves a lot of science. }\end{array}$ & 0.791 \\
\hline
\end{tabular}




\subsection{Mathematics Behaviour}

Of the eight items created to measure mathematical behaviour, three were dropped after statistical analyses suggested that they were not good indicators of mathematical behaviour (see Table 6 and Appendix A Figure S6). Playing Chess (item ST49Q6), programming computers (ST49Q7) and belonging to a mathematics club (ST49Q5) are activities that are not necessarily accessible for all participants. It was understandable that they would not be good indicators of mathematical behaviour. Following this trimming the mathematics behaviour model fit the data well (see Appendix A Figure S6) and it was a reliable factor $(\mathrm{H}=0.765)$.

\subsection{The TPB Model}

The TPB Model outcome from PISA 2012 Australian data is shown in Figure 2.

Table 6. Indicator items of mathematics behavior in the TPB model.

\begin{tabular}{cccc}
\hline $\begin{array}{c}\text { Mathematics } \\
\text { behaviour }\end{array}$ & $\begin{array}{c}\text { Item } \\
\text { number }\end{array}$ & Item & $\begin{array}{c}\text { Factor } \\
\text { loading }\end{array}$ \\
\hline & ST49Q1 & I talk about mathematics problems with my friends. & 0.579 \\
& ST49Q2 & I help my friends with mathematics. & 0.550 \\
& ST49Q3 & I do mathematics as an activity. & 0.721 \\
Coeff H $=0.765$ & ST49Q4 & I take part in mathematics competitions. & 0.623 \\
& ST49Q5 & I do mathematics more than 2 hours a day outside of school. & 0.612 \\
& ST49Q6 & I play chess. & dropped \\
& ST49Q7 & I program computers. & dropped \\
& ST49Q9 & I participate in a mathematics club. & dropped \\
\hline
\end{tabular}

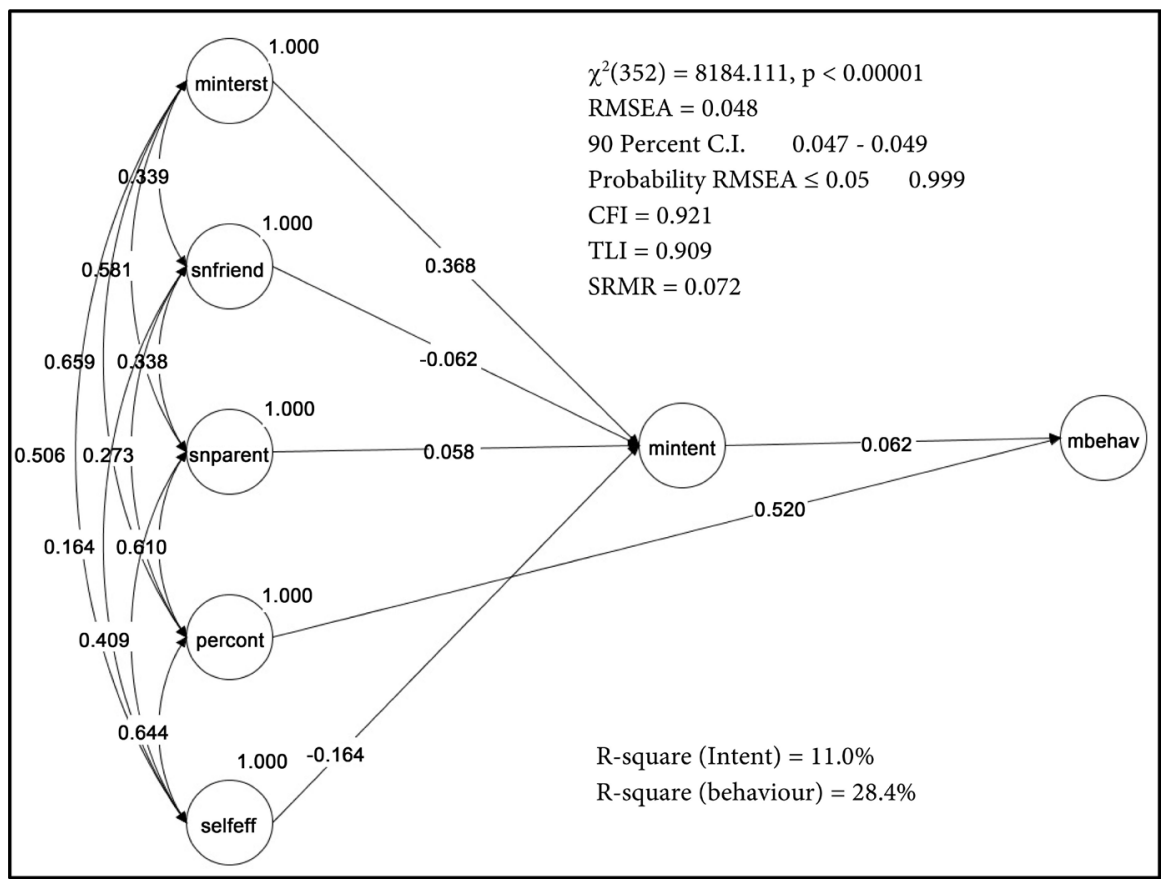

Figure 2. The TPB Model from PISA 2012 Australian data. 
The fit indices indicated that this model was a good fit with the data, although CFI and TLI values were low. In the model it can be seen that attitudes (i.e. an interest in mathematics), the subjective norms of parents and friends, and mathematical self-efficacy were significant predictors of mathematical intentions. However, perceived controllability was found to be a significant predictor of mathematical behaviour, but not of mathematical intentions.

The strongest predictor of mathematical intentions was an interest in mathematics with a regression weight of 0.368 , while the subjective norms of parents factor was a very weak predictor with a regression weight of 0.058 . The negative value of the subjective norms of friends factor, also a weak predictor (with a regression weight of -0.062), suggested that what friends think about mathematics was not instrumental in changing mathematical intentions. In other words, participants had intentions to undertake mathematics, even if their friends did not, and vice versa.

Self-efficacy was a negative, yet weak, predictor of mathematical intentions. While this could seem odd, it could perhaps be explained with reasoning that students who feel confident about completing mathematical exercises of this kind may not see a need to undertake further studies in mathematics.

Since the TPB antecedents were poor predictors of mathematical intentions, accounting for only $11 \%$ of the variance, it is not surprising that the mathematical intentions factor (with a regression weight of 0.062 ) was a very weak predictor of mathematical behaviour.

\section{Discussion}

The results of this study suggest that the hypothesized antecedents in the TPB for mathematics were very poor predictors of mathematical intentions and indirectly, weak predictors of mathematical behaviour. While not a significant predictor of mathematical intentions, but a good predictor of mathematical behaviour, it could be concluded from the findings that perceived control was directly related to mathematical behaviour and that mathematical intentions were not as important. This is quite contrary to the TPB model and therefore demands explanation.

An important advancement in understanding the effect of attitudes on behaviour has been the distinction made by Ajzen and Fishbein (2005) between the use made of general, versus specific, attitudes in the theory. In his review, Wicker (1969) claimed that correlations between attitude and behaviour were generally low and varied in the order of 0.0 to +0.3 . Ajzen and Fishbein's (2005) response to studies with low attitude-behaviour correlations was to draw attention to two types of study inconsistencies, described by Schuman and Johnson (1976) as literal and evaluative inconsistency.

Literal inconsistencies occur when there is a contradiction between what people say they will do (intentions) and what they actually do (actions or behaviours), while evaluative inconsistencies arise in studies where the specific beha- 
viour (action) being investigated fails to correlate with the general attitudes (predictor). Schuman and Johnson (1976) suggested that most of the studies reviewed by Wicker (1969) involved instances of the latter, where inconsistencies arose because the attitude measure was too general. In these early studies researchers mistakenly thought that specific behaviours would reflect broad attitudes and beliefs, but their results suggested otherwise. This contradiction could be avoided, argued Ajzen and Fishbein (2005), by designing studies which employ the "principle of aggregation" (Ajzen \& Fishbein, 2005: 25).

The principle of aggregation involves an assessment of attitudes which relate closely to the behavioural domain of interest, as well as the identification of a broad set of behaviours which relate to the same domain. For example, two people may both hold favourable attitudes towards the church, yet one person may make donations, while the other does not, preferring instead to volunteer her or his time (Fishbein \& Ajzen, 1974). If only monetary donations were to be considered as the behavioural measure, then a favourable attitude towards the church would not be a predictor of behaviour in one out of the two cases investigated. This example illustrates that no one single behaviour will reflect the broad domain being studied. Rather, if broad attitudes are being investigated then the corresponding behaviour must also involve a broad range of actions (i.e., aggregate attitudes must correspond with an aggregate of behaviours). It can be argued that in the PISA 2012 questionnaire items of intention were quite specific given that participants were requested to choose between majoring in mathematics or other subjects. It is clear that the principle of aggregation was violated as attitudes, subjective norms and self-efficacy items were not about majoring in college mathematics.

Furthermore, Ajzen and Fishbein (2005) argued that the principle of aggregation is just a special case of the principle of compatibility. This principle involves ensuring that attitude and behaviour measures are compatible, requiring "that measures of attitude and behaviour involve exactly the same action, target, context, and time elements, whether defined at a very specific or at a more general level" (Ajzen \& Fishbein, 2005: 26). To return to the example above, this means that if a monetary donation to the church is the behaviour of interest, then the attitudes assessed for predictive purposes must espouse sentiments about giving money to the church. Alternatively, if providing church support is the behaviour in question, then both financial support as well as volunteering time would make up part of that behaviour aggregate measure and correspondingly, the attitude measures would include attitudes toward donating time and money to the church.

The supposition is that attitudes need to be specific to the behaviour-using just general or "global" attitudes is insufficient. Defined by Ajzen and Cote (2008) as evaluative dispositions towards a particular object, global attitudes suggest that no particular action is required by the individual towards that object, and they are different to "attitudes towards a behaviour" where an active 
response may be involved. For example, an attitude to mathematics would be a global attitude, while an attitude toward studying mathematics such as majoring in college mathematics, would be an attitude towards a particular behaviour.

The distinction between global and specific behavioural attitudes is very important. Various meta-analyses (e.g., Ajzen \& Fishbein, 1977; Kraus, 1995) have found very poor predictive correlations between global attitudes and specific behaviours. Thus, in this study, attitudes reflected by an interest in mathematics would not be a good predictor of intentions to major in college mathematics. Rather, more specific measures of attitudes, such as attitudes towards majoring in college mathematics, including instrumental as well as behavioural components would be required. Items such as "Doing Maths is fun" and "I enjoy doing maths" would be more appropriate indicators of attitudes towards studying mathematics generally (rather than majoring in it in college).

In a similar vein the law of compatibility would suggest that Subjective Norms should also be specific to the behaviour in question. In this study, questions such as "people who are important to me think that I should major in college mathematics" and "my best friends think that majoring in college mathematics is important", would be more pertinent to majoring in college mathematics than some of the more general statements used in PISA 2012, such as "Most of my friends do well" or "work hard in mathematics", or "My parents like mathematics".

Following this principle, perceived control questions should be more about majoring in college mathematics rather than achievement or doing "well" or doing "badly in mathematics". Items such as "it's hard for me major in college mathematics", or "I can achieve the goal of majoring in college mathematics", might tap into this construct more effectively.

To follow the law of compatibility, questions that measure intentions could be better constructed along a scale which asks students to indicate how likely they might be to choose mathematics as a subject or complete mathematics homework in the future. Such questions would provide a better indicator of mathematical intentions. The current intention questions, which force students to select between majors in Mathematics and English, or between Mathematics and Science, presumes that students have a preference of mathematics over all other subjects and furthermore, that high school students understand the "major" and "minor" structure of tertiary studies.

Elicitation studies designed to elicit people's attitudes, subjective norms and perceived control about a particular type of behaviour are a common procedure amongst TPB researchers to determine specific attitudes, subjective norms and perceived control indicators. Elicitation studies align with Fishbein's (2000) view that in order to develop appropriate measures for the antecedents of intention, it is important to ensure that they fit the population and behaviour in question.

Although an investigator can sit in her or his office and develop measures of attitudes, perceived norms and self-efficacy, she or he cannot tell you what a 
given population (or a given person) believes about performing a given behaviour. Thus one must go to members of that population to identify salient outcome, normative and efficacy beliefs. One must understand the behaviour from the perspective of the population one is considering (Fishbein, 2000: 275).

While it is not known whether the TPB items in PISA 2012 were derived from an elicitation study, future studies would benefit from undertaking this procedure to identify appropriate indicators of the mathematics behaviour being targeted.

A preliminary glance of the findings above might suggest, as Sniehotta, Presseau and Araújo-Soares (2014) have argued that it might be time to retire the TPB. However, the argument that test items could be ill-defined and violate the principles of aggregation and compatibility should not be dismissed or ignored. It could well be that the TPB is difficult to understand and apply, but that too is no grounds for "retiring" it. Rather, until that step is taken we would suggest more empirical studies that comply with the principles underlying the TPB as intended by the original theorists be undertaken by erudite researchers.

\section{Conclusion}

Due to the poor predictive power of mathematical intentions and behaviour using TPB antecedents of attitudes, subjective norms and perceived control, one could conclude that the TPB is not applicable in the mathematics context. However, as Ma and Kishor (1997) similarly found in their meta-analysis nearly two decades ago, the poor predictive capacity of the TPB may be due to ill-defined indicator items in the measuring instruments that have not complied with the principle of compatibility.

\section{References}

Ajzen, I. (1985). From Intentions to Actions: A Theory of Planned Behavior. In J. Kuhl, \& J. Beckman (Eds.), Action-Control: From Cognition to Behavior (pp. 11-39). Heidelberg: Springer. https://doi.org/10.1007/978-3-642-69746-3_2

Ajzen, I. (1988). Attitudes, Personality, and Behavior. Milton-Keynes: Open University Press.

Ajzen, I. (1991) The Theory of Planned Behavior. Organizational Behavior and Human Decision Processes, 50, 179-211. https://doi.org/10.1016/0749-5978(91)90020-T

Ajzen, I. (2002). Residual Effects of Past on Later Behavior: Habituation and Reasoned Action Perspectives. Personality and Social Psychology Review, 6, 107-122. https://doi.org/10.1207/S15327957PSPR0602_02

Ajzen, I., \& Albarracin, D. (2007). Predicting and Changing Behavior: A Reasoned Action Approach. In I. Ajzen, D. Albarracin, \& R. Hornik (Eds.), Prediction and Change of Health Behavior: Applying the Reasoned Action Approach (pp. 3-22). Mahwah, NJ: Lawrence Erlbaum Assoc.

Ajzen, I., \& Cote, N. G. (2008). Attitudes and the Prediction of Behavior. In W. D. Crano, \& R. Prislin (Eds.), Attitudes and Attitude Change (pp. 289-311). New York, NY: Psychology Press.

Ajzen, I., \& Driver, B. L. (1992). Application of the Theory of Planned Behavior to Leisure 
Choice. Journal of Leisure Research, 24, 207-224.

Ajzen, I., \& Fishbein, M. (1977). Attitude-Behavior Relations: A Theoretical Analysis and Review of Empirical Research. Psychological Bulletin, 84, 888-918. https://doi.org/10.1037/0033-2909.84.5.888

Ajzen, I., \& Fishbein, M. (2005). The Influence of Attitudes on Behavior. In D. Albarracin, B. T. Johnson, \& M. P. Zanna (Eds.), The Handbook of Attitudes (pp. 173-221). Mahwah, NJ: Erlbaum.

Ajzen, I., \& Manstead, A. S. (2007). Changing Health-Related Behaviors: An Approach Based on the Theory of Planned Behavior. In K. van den Bos, M. Hewstone, J. de Wit, H. Schut, \& M. Stroebe (Eds.), The Scope of Social Psychology: Theory and Applications (pp. 43-63). New York, NY: Psychology Press.

Albarracin, D., Johnson, B. T., Fishbein, M., \& Muellerleile, P. A. (2001). Theories of Reasoned Action and Planned Behavior as Models of Condom Use: A Meta-Analysis. Psychological Bulletin, 127, 142-161. https://doi.org/10.1037/0033-2909.127.1.142

Armitage, C. J. (1997). Social Cognitive Determinants of, Food Choice and Dietary Change. Unpublished Doctoral Dissertation, University of Leeds.

Armitage, C. J., \& Conner, M. (2001). Efficacy of the Theory of Planned Behavior: A Meta-Analytic Review. British Journal of Social Psychology, 40, 471-499. https://doi.org/10.1348/014466601164939

Armstrong, J. M. (1980). Achievement and Participation of Women in Mathematics: An Overview. Report of a Two-Year Study. Denver, CO: Education Commission of the States.

Berg, C., Jonsson, I., \& Conner, M. (2000). Understanding Choice of Milk and Bread for Breakfast among Swedish Children Aged 11-15 Years: An Application of the Theory of Planned Behaviour. Appetite, 34, 5-19. https://doi.org/10.1006/appe.1999.0269

Brown, T. A. (2006). Confirmatory Factor Analysis for Applied Research. New York, NY: The Guilford Press.

Browne, M. W., \& Cudeck, R. (1993). Alternate Ways of Assessing Model Fit. In K. A. Bollen, \& J. S. Long (Eds.), Testing Structural Equation Models (pp. 136-162). Newbury Park, CA: Sage.

Brunner, M., \& Heinz-Martin, S. (2005). Analyzing the Reliability of Multidimensional Measures: An Example from Intelligence Research. Educational and Psychological Measurement, 65, 227-240. https://doi.org/10.1177/0013164404268669

Chen, P. P. (2002). Exploring the Accuracy and Predictability of the Self-Efficacy Beliefs of Seventh-Grade Mathematics Students. Learning and Individual Differences, 14, 77-90. https://doi.org/10.1016/j.lindif.2003.08.003

Chinnappan, M., Dinham, S., Herrington, A., \& Scott, D. (2008). Year 12 Students and Higher Mathematics: Emerging Issues. Paper Presented at the Australian Association for Research in Education Conference. http://ro.uow.edu.au/edupapers/684/

Cialdini, R. B. (2003). Crafting Normative Messages to Protect the Environment. Current Directions in Psychological Science, 12, 105-109. https://doi.org/10.1111/1467-8721.01242

Conner, M., \& Armitage, C. J. (1998). Extending the Theory of Planned Behavior: A Review and Avenues for Further Research. Journal of Applied Social Psychology, 28, 1429-1464. https://doi.org/10.1111/j.1559-1816.1998.tb01685.x

Crites, S. L., Fabrigar, L. R., \& Petty, R. E. (1994). Measuring the Affective and Cognitive Properties of Attitudes: Conceptual and Methodological Issues. Personality and Social Psychology Bulletin, 20, 619-634. https://doi.org/10.1177/0146167294206001 
Di Martino, P., \& Zan, R. (2010). "Me and Maths": Toward a Definition of Attitude Ground on Students' Narratives. Journal of Mathematics Teacher Education, 13, 27-48. https://doi.org/10.1007/s10857-009-9134-Z

Dzewaltowski, D. A., Noble, J. M., \& Shaw, J. M. (1990). Physical Activity Participation: Social Cognitive Theory versus the Theories of Reasoned Action and Planned Behavior. Journal of Sport \& Exercise Psychology, 12, 388-405. https://doi.org/10.1123/jsep.12.4.388

Eccles, J. (1983). Expectancies, Values, and Academic Behaviors. In J. T. Spence (Ed.), Achievement and Achievement Motives: Psychological and Sociological Approaches (pp. 75-146). San Francisco, CA: Freeman.

Fishbein, M. (2000). The Role of Theory in HIV Prevention. AIDS Care, 12, 273-278. https://doi.org/10.1080/09540120050042918

Fishbein, M. (2008). A Reasoned Action Approach to Health Promotion. Medical Decision Making, 28, 834-844. https://doi.org/10.1177/0272989X08326092

Fishbein, M., \& Ajzen, I. (1974). Attitudes towards Objects as Predictors of Single and Multiple Behavioral Criteria. Psychological Review, 81, 59-74. https://doi.org/10.1037/h0035872

Fishbein, M., \& Ajzen, I. (1975). Belief, Attitude, Intention and Behavior: An Introduction to Theory and Research. Reading, MA: Addison-Wesley.

Fishbein, M., \& Ajzen, I. (2005). Theory-Based Behavior Change Interventions: Comments on Hobbis and Sutton. Journal of Health Psychology, 10, 27-31. https://doi.org/10.1177/1359105305048552

Forgasz, H. J. (2006a). Australian Year 12 Mathematics Enrolments: Patterns and Trends, Past and Present. Melbourne, Vic: Australian Mathematical Sciences Institute. https://amsi.org.au/wp-content/uploads/2015/01/Forgasz_2006_Y12_Mathematics_En rolments.pdf

Forgasz, H. J. (2006b). Australian Year 12 “Intermediate” Level Mathematics Enrolments 2000-2004: Trends and Patterns. In Identities, Cultures and Learning Spaces (Vol. 1). Canberra: ACT. http://www.merga.net.au/documents/RP222006.pdf

Georgiou, S. N., Stavrinides, P., \& Kalavana, T. (2007). Is Victor Better than Victoria at Maths? Educational Psychology in Practice, 23, 329-342. https://doi.org/10.1080/02667360701660951

Godin, G., \& Kok, G. (1996). The Theory of Planned Behavior: A Review of Its Applications to Health-Related Behaviors. American Journal of Health Promotion, 11, 87-98. https://doi.org/10.4278/0890-1171-11.2.87

Gunderson, E. A., Ramirez, G., Levine, S. C., \& Beilock, S. L. (2012). The Role of Parents and Teachers in the Development of Gender-Related Math Attitudes. Sex Roles, 66, 153-166. https://doi.org/10.1007/s11199-011-9996-2

Hagger, M. S., \& Chatzisarantis, N. L. (2005). First- and Higher-Order Models of Attitudes, Normative Influence, and Perceived Behavioural Control in the Theory of Planned Behaviour. British Journal of Social Psychology, 44, 513-535. https://doi.org/10.1348/014466604X16219

Hagger, M. S., Chatzisarantis, N. L., \& Biddle, S. J. (2002). The Influence of Autonomous and Controlling Motives on Physical Activity Intentions within the Theory of Planned Behaviour. British Journal of Health Psychology, 7, 283-298. https://doi.org/10.1348/135910702760213689

Hancock, G. R., \& Mueller, R. O. (2001). Rethinking Construct Reliability within Latent Variable Systems. In R. Cudeck, S. D. Toit, \& D. Soerbom (Eds.), Structural Equation 
Modeling: Present and Future-A Festschrift in Honor of Karl Jöreskog (pp. 195-216). Lincolnwood, IL: Scientific Software International.

Hanulla, M. S. (2002). Attitude towards Mathematics: Emotions, Expectations and Values. Educational Studies in Mathematics, 49, 25-46. https://doi.org/10.1023/A:1016048823497

Hausenblas, H. A., Carron, A. V., \& Mack, D. E. (1997). Application of the Theories of Reasoned Action. Journal of Sport \& Exercise Psychology, 19, 36-51. https://doi.org/10.1123/jsep.19.1.36

Hoffman, B. (2010). "I Think I Can, But I'm Afraid to Try”: The Role of Self-Efficacy Beliefs and Mathematics Anxiety in Mathematics Problem-Solving Efficiency. Learning and Individual Differences, 20, 276-283. https://doi.org/10.1016/j.lindif.2010.02.001

Holmes-Smith, P., \& Rowe, K. J. (1994). The Development and Use of Congeneric Measurement Models in School Effectiveness Research: Improving the Reliability and Validity of Composite and Latent Variables for Fitting Multilevel and Structural Equation Models. In International Congress for School Effectiveness and Improvement. Melbourne: The World Congress Centre.

Jacobs, J. E., \& Bleeker, M. M. (2004). Girls' and Boys' Developing Interests in Math and Science: Do Parents Matter? New Directions for Child and Adolescent Development, 2004, 5-21. https://doi.org/10.1002/cd.113

Jacobs, J. E., \& Eccles, J. S. (2000). Parents, Task Values, and Real-Life Achievement-Related Choices. In C. Sansone, \& J. M. Harackiewicz (Eds.), Intrinsic and EXtrinsic Motivation: The Search for Optimal Motivation and Performance (pp. 405-439). San Diego, CA: Academic Press. https://doi.org/10.1016/B978-012619070-0/50036-2

Jeffries, D. (2016). Factors That Influence STEM Subject Choice in Year 12. Unpublished PhD Proposal, Flinders University Adelaide.

Johnson, D. W., \& Johnson, R. T. (2005). New Developments in Social Interdependence Theory. Genetic, Social, and General Psychology Monographs, 131, 285-358. https://doi.org/10.3200/MONO.131.4.285-358

Kadijevich, D. (2006). Developing Trustworthy TIMSS Background Measures: A Case Study on Mathematics Attitude. The Teaching of Mathematics, 9, 41-51.

Kalaycioglua, D. B. (2015). The Influence of Socioeconomic Status, Self-Efficacy, and Anxiety on Mathematics Achievement in England, Greece, Hong Hong, the Netherlands, Turkey, and the USA. Educational Sciences: Theory \& Practice, 15, 1391-1401.

Kaplan, A., Middleton, M. J., Urdan, T., \& Midgley, C. (2002). Achievement Goals and Goal Structures. In C. Midgley (Ed.), Goals, Goal Structures, and Patterns of Adaptive Learning (pp. 21-53). Mahwah, NJ: Erlbaum.

Kashima, Y., Gallois, C., \& McCamish, M. (1993). The Theory of Reasoned Action and Cooperative Behaviour: It Takes Two to Use a Condom. British Journal of Social Psychology, 32, 227-239. https://doi.org/10.1111/j.2044-8309.1993.tb00997.x

Kennedy, J. P., Lyons, T., \& Quinn, F. (2014). The Continuing Decline of Science and Mathematics Enrolments in Australian High Schools. Teaching Science, 60, 34-46.

Kline, R. B. (2011). Principles and Practice of Structural Equation Modeling (3rd ed.). New York, NY: The Guilford Press.

Kogce, D., Yildiz, C., Aydin, M., \& Altindag, R. (2009). Examining Elementary School Studentes' Attitudes towards Mathematics in Terms of Some Variables. Procedia, 1, 291-295.

Kraus, S. J. (1995). Attitudes and the Prediction of Behavior: A Meta-Analysis of the Empirical Literature. Personality and Social Psychology Bulletin, 21, 58-75. 
https://doi.org/10.1177/0146167295211007

Lipnevich, A. A., MacCann, C., Krumm, S., Burrus, J., \& Roberts, R. D. (2011). Mathematics Attitudes and Mathematics Outcomes of US and Belarusian Middle School Students. Journal of Educational Psychology, 103, 105-118. https://doi.org/10.1037/a0021949

Lyons, T., \& Quinn, F. (2010). Choosing Science: Understanding the Declines in Senior High School Science Enrolments. National Centre of Science, ICT and Mathematics Education for Rural and Regional Australia (SiMERR Australia), University of New England.

Ma, X. (2001). Participation in Advanced Mathematics: Do Expectation and Influence of Students, Peers, Teachers, and Parents Matter? Contemporary Educational Psychology, 26, 132-146. https://doi.org/10.1006/ceps.2000.1050

Ma, X., \& Kishor, N. (1997). Assessing the Relationship between Attitude toward Mathematics and Achievement in Mathematics: A Meta-Analysis. Journal for Research in Mathematics Education, 28, 26-47. https://doi.org/10.2307/749662

Ma, X., \& Xu, J. (2004). Determining the Causal Ordering between Attitude toward Mathematics and Achievement in Mathematics. American Journal of Education, 110, 256-280. https://doi.org/10.1086/383074

Manstead, A. S., \& Eekelen, S. A. (1998). Distinguishing between Perceived Behavioral Control and Self-Efficacy in the Domain of Academic Achievement Intentions and Behaviors. Journal of Applied Social Psychology, 28, 1375-1392. https://doi.org/10.1111/j.1559-1816.1998.tb01682.x

Mata, M. D. L., Monteiro, V., \& Peixoto, F. (2012). Attitudes towards Mathematics: Effects of Individual, Motivational, and Social Support Factors. Child Development Research, 2012, Article ID: 876028. https://doi.org/10.1155/2012/876028 http://www.hindawi.com/journals/cdr/2012/876028/abs/

Mato Vázquez, M. D., \& de la Torre Fernández, E. (2009). Evaluación de las actitudes hacia las matemáticas yel rendimiento academic. [Assessment of Attitudes towards Mathematics and Academic Performance.] In M. J. González, M. T. González, \& J. Murillo (Eds.), Investigación en Educación Matemática [Research in Mathematics Education] (pp. 285-300, Vol. 13). Santander: SEIEM.

McCaul, K. D., Sandgren, A. K., O’Neill, H. K., \& Hinsz, V. B. (1993). The Value of the Theory of Planned Behavior, Perceived Control, and Self-Efficacy Expectations for Predicting Health-Protective Behaviors. Basic and Applied Social Psychology, 14, 231-252. https://doi.org/10.1207/s15324834basp1402_7

McLeod, D. B. (1987). A Constructivist Approach to Research on Attitude toward Mathematics. In J. C. Bergeron (Ed.), Proceedings of the 11th International Conference of the International Group for the Psychology of Mathematics Education (Vol. I, pp. 133-139). Montreal: PME.

Mohamed, L., \& Waheed, H. (2011). Secondary Students' Attitude towards Mathematics in a Selected School of Maldives. International Journal of Humanities and Social Science, 1, 227-281.

Muthén, L. K., \& Muthén, B. O. (2009). MPlus User's Guide (5th ed.). Los Angeles, CA: Muthén \& Muthén.

Nicolaidou, M., \& Philippou, G. (2003). Attitudes towards Mathematics, Self-Efficacy and Achievement in Problem Solving. In M. A. Mariotti (Ed.), European Research in Mathematics Education III (pp.1-11). Italy: University of Pisa.

OECD (2012). PISA 2012 Assessment and Analytical Framework. Mathematics, Reading, 
Science, Problem Solving and Financial Literacy. Paris: OECD Publishing.

OECD (2014). PISA 2012 Technical Report. https://www.oecd.org/pisa/pisaproducts/PISA-2012-technical-report-final.pdf

Pajares, F., \& Graham, L. (1999). Self-Efficacy, Motivation Constructs, and Mathematics Performance of Entering Middle School Students. Contemporary Educational Psychology, 24, 124-139. https://doi.org/10.1006/ceps.1998.0991

Rivis, A., \& Sheeran, P. (2003). Descriptive Norms as an Additional Predictor in the Theory of Planned Behaviour: A Meta-Analysis. Current Psychology, 22, 218-233. https://doi.org/10.1007/s12144-003-1018-2

Ryan, A. M., \& Patrick, H. (2001). The Classroom Social Environment and Changes in Adolescents' Motivation and Engagement during Middle School. American Educational Research Journal, 38, 437-460. https://doi.org/10.3102/00028312038002437

Sage, N. A., \& Kindermann, T. A. (1999). Peer Networks, Behavior Contingencies, and Children's Engagement in the Classroom. Merrill-Palmer Quarterly, 1982, 143-171.

Schuman, H., \& Johnson, M. P. (1976). Attitudes and Behavior. Annual Review of Sociology, 2, 161-207. https://doi.org/10.1146/annurev.so.02.080176.001113

Sheeran, P., \& Orbell, S. (1998). Do Intentions Predict Condom Use? Meta-Analysis and Examination of Six Moderator Variables. British Journal of Social Psychology, 37, 231-250. https://doi.org/10.1111/j.2044-8309.1998.tb01167.x

Sheeran, P., \& Taylor, S. (1999). Predicting Intentions to Use Condoms: A Meta-Analysis and Comparison of the Theories of Reasoned Action and Planned Behavior. Journal of Applied Social Psychology, 29, 1624-1675.

https://doi.org/10.1111/j.1559-1816.1999.tb02045.x

Sheeran, P., Norman, P., \& Orbell, S. (1999). Evidence That Intentions Based on Attitudes Better Predict Behaviour than Intentions Based on Subjective Norms. European Journal of Social Psychology, 29, 403-406.

https://doi.org/10.1002/(SICI)1099-0992(199903/05)29:2/3<403::AID-EJSP942>3.0.CO; $\underline{2-\mathrm{A}}$

Siegel, R. G., Galassi, J. P., \& Ware, W. B. (1985). A Comparison of Two Models for Predicting Mathematics Performance: Social Learning versus Math Aptitude-Anxiety. Journal of Counseling Psychology, 32, 531-538. https://doi.org/10.1037/0022-0167.32.4.531

Sniehotta, F. F., Presseau, J., \& Araújo-Soares, V. (2014). Time to Retire the Theory of Planned Behavior. Health Psychology Review, 8, 1-7. https://doi.org/10.1080/17437199.2013.869710

Stevens, T., Olivarez, A., Lan, W. Y., \& Tallent-Runnels, M. K. (2004). Role of Mathematics Self-Efficacy and Motivation in Mathematics Performance across Ethnicity. The Journal of Educational Research, 97, 208-222. https://doi.org/10.3200/JOER.97.4.208-222

Terry, D. J., \& O’Leary, J. E. (1995). The Theory of Planned Behaviour: The Effects of Perceived Behavioural Control and Self-Efficacy. British Journal of Social Psychology, 34, 199-220. https://doi.org/10.1111/j.2044-8309.1995.tb01058.x

Thomas, J. (2000). Mathematical Sciences in Australia: Looking for a Future. Deakin: Federation of Australian Scientific and Technological Societies.

Thomas, S., De Bortoli, L., \& Buckley, S. (2013). PISA 2012: How Australia Measures up. Victoria: Australian Council for Educational Research.

Tiedemann, J. (2000). Parents' Gender Stereotypes and Teachers' Beliefs as Predictors of Children's Concept of Their Mathematical Ability in Elementary School. Journal of 
Educational Psychology, 92, 144-151. https://doi.org/10.1037/0022-0663.92.1.144

Trafimow, D., Sheeran, P., Conner, M., \& Finlay, K. A. (2002). Evidence That Perceived Behavioural Control Is a Multidimensional Construct: Perceived Control and Perceived Difficulty. British Journal of Social Psychology, 41, 101-121. https://doi.org/10.1348/014466602165081

White, K. M., Terry, D. J., \& Hogg, M. A. (1994). Safer Sex Behavior: The Role of Attitudes, Norms, and Control Factors. Journal of Applied Social Psychology, 24, 2164-2192. https://doi.org/10.1111/j.1559-1816.1994.tb02378.x

Wicker, A. W. (1969). Attitudes versus Actions: The Relationship of Verbal and Overt Behavioral Responses to Attitude Objects. Journal of Social Issues, 25, 41-78. https://doi.org/10.1111/j.1540-4560.1969.tb00619.x

Yee, D. K., \& Eccles, J. S. (1988). Parent Perceptions and Attributions for Children's Math Achievement. Sex Roles, 19, 317-333. https://doi.org/10.1007/BF00289840

Zan, R., \& Di Martino, P. (2008). Attitude toward Mathematics: Overcoming the Positive/Negative Dichotomy. In B. Sriraman (Ed.), Beliefs and Mathematics: Festschrift in Honor of Guenter Toerner's 60th Birthday (pp. 197-214). Missoula, MT: Information Publishing Age Publishing.

Zimmerman, B. J. (1995). Self-Efficacy and Educational Development. In A. Bandura (Ed.), Self-Efficacy in Changing Societies (pp. 202-231). New York, NY: Cambridge University Press. https://doi.org/10.1017/CBO9780511527692.009 


\section{Appendix A}

\section{Attitudes (Interest)}

The initial model prior to the error in two items being freed to correlate had the following fit indices: $\chi^{2}(2)=79.804, p<0.00001$, RMSEA $=0.064,90$ Percent C.I. $=0.053-0.077$, Probability RMSEA $\leq 0.05=0.023$, CFI $=0.996$, TLI $=0.987$, SRMR $=0.009$. This was not the best fit with the data.

\section{Subjective Norms}

Initial model prior to forming two sub-factors and allowing the error in four items to correlate had the following fit indices: $\chi^{2}(9)=4687.681, p<0.00001$, RMSEA $=0.234,90$ Percent C.I. $=0.229-0.240$, Probability RMSEA $\leq 0.05=$ $0.000, \mathrm{CFI}=0.572, \mathrm{TLI}=0.287, \mathrm{SRMR}=0136$.

RMSEA $=0.037$
90 Percent C.I.0.021 0.055
Probability RMSEA $\leq 0.05$
CFI $=0.999$
$\mathrm{TLI}=0.996$
$\mathrm{SRMR}=0.003$

Figure S1. CFA of the attitudes construct in the TPB model.

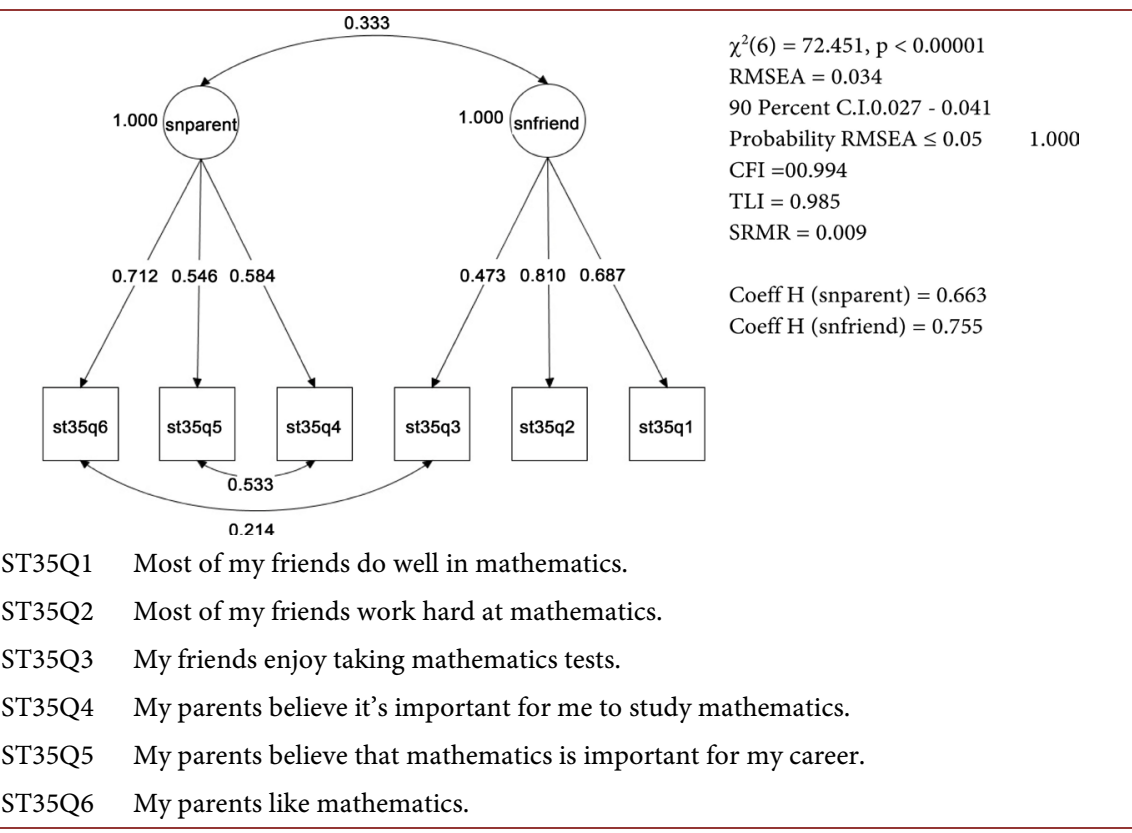

Figure S2. CFA of the subjective norms construct in the TPB model. 


\section{Perceived Control}

Initial model prior to trimming (dropping obscure items ST43Q3 and ST43Q4) and allowing the error in two items to correlate had the following fit indices: $\chi^{2}(9)=1253.058, p<0.00001$, RMSEA $=0.121,90$ Percent C.I. $=0.115-0.127$, Probability RMSEA $\leq 0.05=0.000, \mathrm{CFI}=0.799, \mathrm{TLI}=0.665, \mathrm{SRMR}=0.070$.

\section{Self-Efficacy}

Initial model prior to trimming (dropping items ST37Q4 and ST37Q8 - which young people may be unfamiliar with) and allowing the error in three items to correlate had the following fit indices: $\chi^{2}(20)=2196.085, p<0.00001$, RMSEA $=$ 0.107, 90 Percent C.I. $=0.104-0.111$, Probability RMSEA $\leq 0.05=0.000$, CFI $=$ $0.914, \mathrm{TLI}=0.880, \mathrm{SRMR}=0.046$.

\section{Mathematics Intentions}

Initial model prior to trimming (dropping ambiguous item ST48Q1) and allowing the error in two items to correlate had the following fit indices: $\chi^{2}(5)=$ 2005.907, $p<0.00001$, RMSEA $=0.210,90$ Percent C.I. $=0.202-0.217$, Probability RMSEA $\leq 0.05=0.000, \mathrm{CFI}=0.794, \mathrm{TLI}=0.588, \mathrm{SRMR}=0.107$.

\section{Mathematics Behaviour}

Initial model prior to trimming (dropping 3 item ST49Q6, ST49Q7 and ST49Q9, which are not very common among students) and allowing the error in two items to correlate had the following fit indices: $\chi^{2}(20)=1398.572, p<0.00001$, RMSEA $=0.086,90$ Percent C.I. $=0.082-0.089$, Probability RMSEA $\leq 0.05=$ $0.000, \mathrm{CFI}=0.857, \mathrm{TLI}=0.800, \mathrm{SRMR}=0.057$.

$\begin{aligned} & \chi^{2}(1)=2.192, \mathrm{p}>0.05 \\ & \mathrm{RMSEA}=0.011 \\ & 90 \text { Percent } \mathrm{C} . \mathrm{I} . \\ & \text { Probability RMSEA } 0.000-0.032 \\ & \mathrm{CFI}=1.000 \\ & \mathrm{TLI}=0.998 \\ & \text { SRMR }=0.003\end{aligned}$
ST43Q1

Figure S3. CFA of the perceived behavioural control construct in the TPB model. 


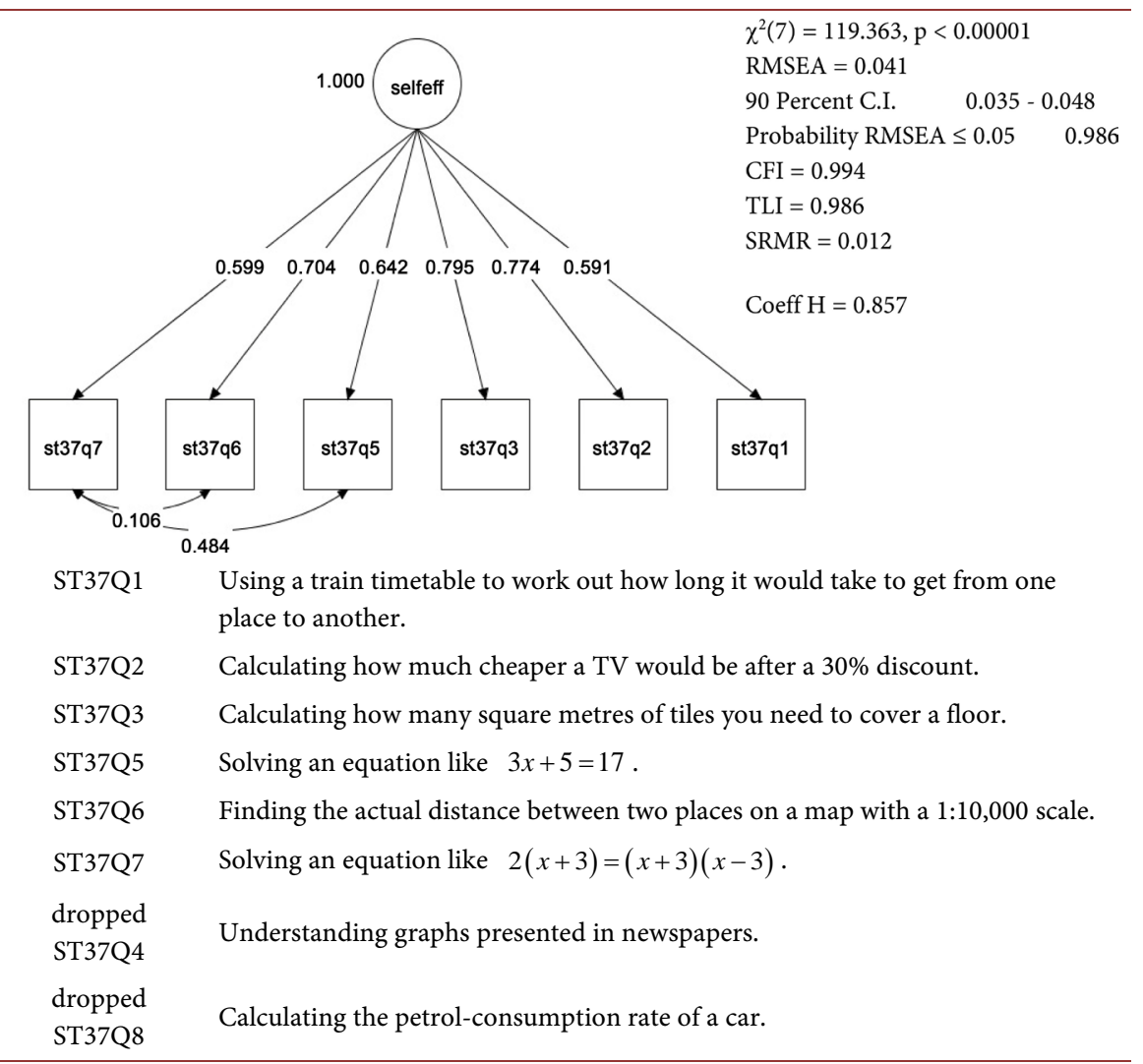

Figure S4. CFA of the self-efficacy construct in the TPB model.

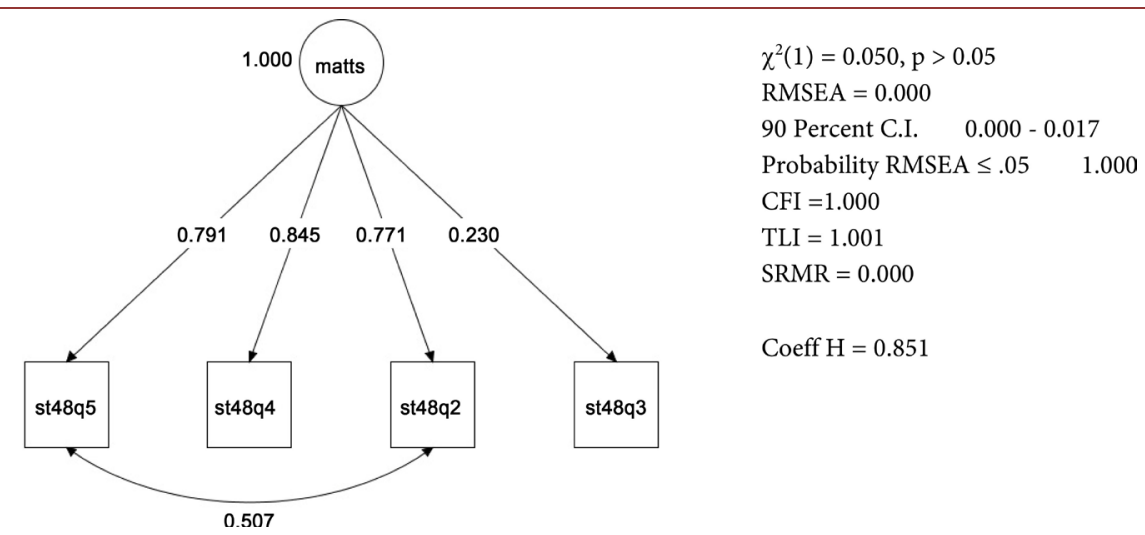

ST48Q2 I plan on majoring in a subject in college that requires mathematics skills vs. I plan on majoring in a subject in college that requires science skills.

ST48Q3 I am willing to study harder in my mathematics classes than is required vs. I am willing to study harder in my English classes than is required.

ST48Q4 I plan on taking as many mathematics classes as I can during my education vs. I plan on taking as many science classes as I can during my education.

ST48Q5 I am planning on pursuing a career that involves a lot of mathematics vs. I am planning on pursuing a career that involves a lot of science.

Dropped I intend to take additional mathematics courses after school finishes vs. I intend ST48Q1 to take additional English courses after school finishes.

Figure S5. CFA of the mathematics intention construct in the TPB model. 


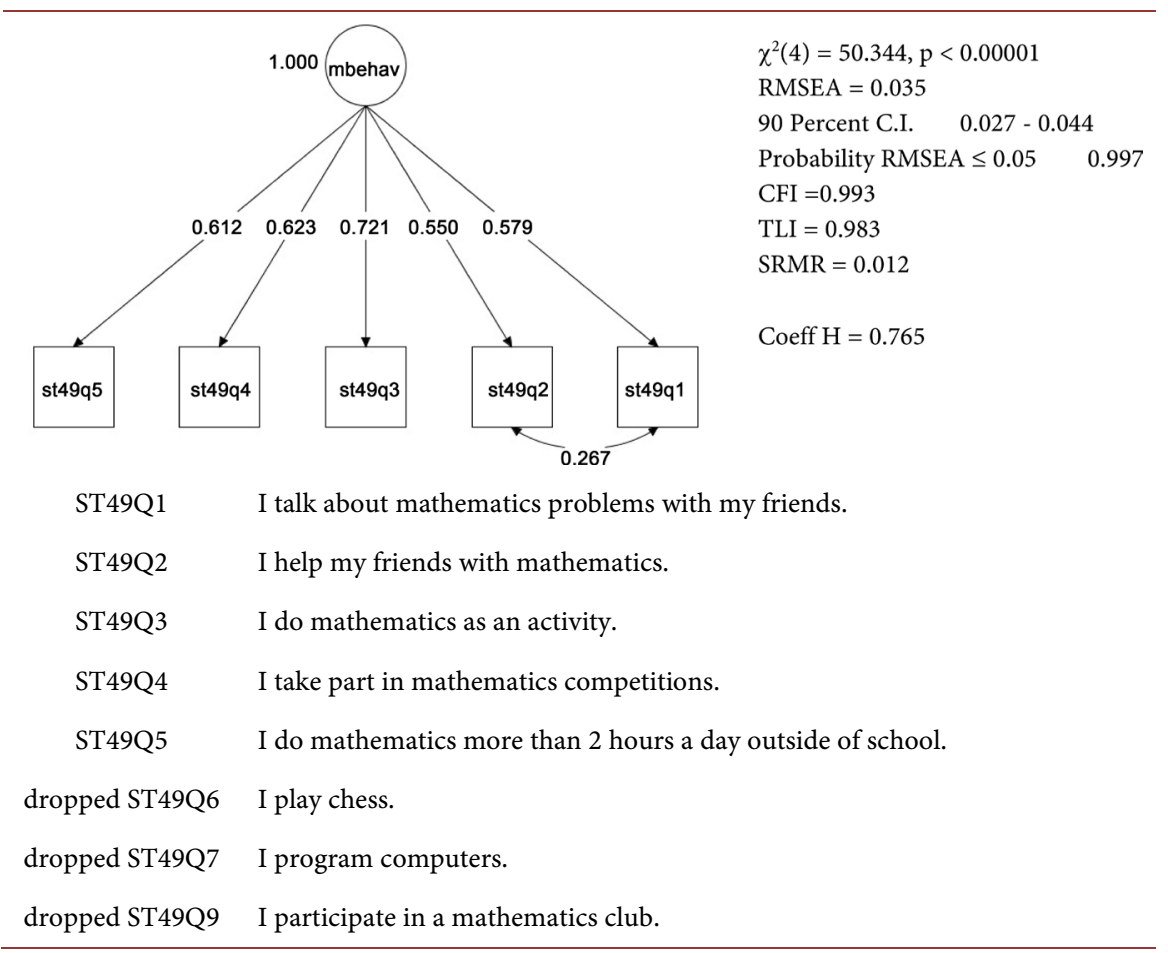

Figure S6. CFA of the mathematics behaviour construct in the TPB model. 